\title{
NOTES ON THE NATURAL HISTORY OF CYCLOPOGON OBLIQUUS (ORCHIDACEAE: SPIRANTHINAE) IN COSTA RICA
}

\author{
Mario A. Blanco \\ Instituto Centroamericano de Investigación Biológica y Conservación \\ P.O. Box 2398-250, San Pedro de Montes de Oca, San José, Costa Rica \\ Research Associate, Jardín Botánico Lankester, Universidad de Costa Rica \\ Present mailing address: University of Florida, Department of Botany, 220 Bartram Hall \\ P.O. Box 118526 Gainesville, Florida 32611-8526, U.S.A. mblanco@ flmnh.ufl.edu
}

\begin{abstract}
The occurrence of Cyclopogon obliquus (J.J. Sm.) Szlach. [= Pelexia obliqua (J. J. Sm.) Garay] is reported for the first time in Costa Rica. Its taxonomic placement is discussed, and its current geographic distribution is reviewed. Observations on its habitat, phenology and reproduction are presented.

Resumen. Se presenta el primer informe de la existencia de Cyclopogon obliquus (J.J. Sm.) Szlach. [= Pelexia obliqua (J. J. Sm.) Garay] en Costa Rica. Se discute su posición taxonómica y se presenta una revisión de su actual distribución geográfica. Se presentan observaciones sobre su hábitat, fenología y reproducción.
\end{abstract}

Key words / Palabras Clave: Orchidaceae, Cyclopogon, Pelexia, Spiranthinae, Costa Rica, pantropical species, phenology, deciduousness, autogamy.

In April 2000, I found a leafless, terrestrial Spiranthine orchid with small whitish flowers at La Selva Biological Station, in Heredia province, Costa Rica. It was immediately apparent that it was a novelty for the site's orchid flora (revised by Atwood 1988, Wilbur 1994), but its identity was a mystery to me. There were remains of dead leaves at the bases of the plants, indicating that they were deciduous. Flowering while leafless is characteristic of a number of genera in the Spiranthinae, including Sarcoglottis, Funkiella, Brachystele, Spiranthes, and Schiedeella. Most species in other genera produce flowers while their leaves are still present. This vegetative dichotomy originally led me to believe that the plant in question belonged in the former group. Assuming it to be a species of Schiedeella Schltr., I concluded it was a new species, and prepared a description.

Fortunately, Gerardo Salazar - who is studying the generic delimitations within Spiranthinae - saw the description and recognized the plant as a species of Cyclopogon, and suggested it might be the enigmatic C. obliquus (J.J. Sm.) Szlach., which I was later able to confirm. So, the publication of another superfluous name for this taxon was prevented (see below).

The accompanying illustration (Fig. 1) and following description are based on the two Costa Rican collections, which constitute the first report of this species for the country. In Central America, the species was previously reported to the north of Costa Rica (Dressler 1993, and references below). Both MoraRetana \& García (1992) and Dressler (1993) listed it as a species of potential occurrence in Costa Rica, because of its previous report from southern Nicaragua. Other diagnostic illustrations can be found in Hamer (1981, as Pelexia hameri, and 1984, 1990, as Pelexia obliqua) and $\mathrm{Hu}$ (1977, as Manniella hongkongensis).

Cyclopogon obliquus (J. J. Sm.) Szlach., Fragm. Florist. Geobot. 39(2): 425. $1994 . \quad$ FIG. 1

BASIONYM: Spiranthes obliqua J. J. Sm., Bull. Dép. Agric. Indes Néerl. 43: 74. 1910. TYPE: Indonesia, Java, Buitenzorg (Bogor), J. J. Smith s.n. (BO, not seen).

SYNONYMS: Manniella hongkongensis S. Y. Hu \& G. Barretto, Chung Chi J. 13(2): 6. 1976. TYPE: China, Hong Kong, S. Y. Нu 13266 (K, not seen). Pelexia hameri Garay, Bot. Mus. Leafl. Harv. Univ. 26(1): 22. 1978. TYPE: El Salvador, $O$. Pank in F. Hamer 613 (AMES, photo!).

Pelexia obliqua (J. J. Sm.) Garay, Bot. Mus. Leafl. Harv. Univ. 28(4): 345. 1980.

Plant a terrestrial herb, geophyte. Roots 3 to 6 in flowering individuals, tuberous, fusiform, $1-4.5 \mathrm{~cm}$ 
long, 6-9 $\mathrm{mm}$ thick at the widest point, white-cream, covered with short hairs when young (early leafing stage), glabrous when leafless. Leaves petiolate, convolute, produced in a basal rosette, 6 or more in number, held flat against the ground when mature, absent at flowering; petiole white to light green, 4-14 mm long, 2-5 $\mathrm{mm}$ thick (longer and thinner in the first smaller leaves), base sheathing; lamina elliptic, acute apically, $1.5-5.8 \mathrm{~cm}$ long, $0.8-2.8 \mathrm{~cm}$ wide, decurrent onto the petiole, shiny dark green adaxially, crystalline light green abaxially, with a greenish-white thick ( $2 \mathrm{~mm}$ at base) midvein and two main secondary veins diverging from near the base of the lamina; tertiary venation reticulate, faintly visible adaxially. Inflorescence terminal, erect, spicatepedunculate, $13-32 \mathrm{~cm}$ long. Peduncle terete, puberulous, 9-20 cm long, 1-3 mm thick, light green, covered by 4-6 sheathing bracts. Spike dense, $4.5-15 \mathrm{~cm}$ long, 9-40 flowered, with 2-4 flowers open at a time. Peduncular bracts sheathing, linear-triangular, 2-4 $\mathrm{cm}$ long, 3-5 $\mathrm{mm}$ wide at the base, pale green. Floral bracts subulate-caudate, up to $6 \mathrm{~mm}$ long and $1.5 \mathrm{~mm}$ wide, scarious. Flowers resupinate, straight to slightly nodding at the junction of perianth and ovary. Ovary fusiform, trigonous, $8 \mathrm{~mm}$ long, $2.2 \mathrm{~mm}$ thick, light green; spur completely adnate to the ovary, $2.6 \mathrm{~mm}$ long, $0.8 \mathrm{~mm}$ wide, covered with glandular hairs to $0.3 \mathrm{~mm}$ long. Sepals greenish light-brown, externally puberulous. Dorsal sepal oblong-lanceolate, obtuse to rounded, slightly concave at the base, $4.3 \mathrm{~mm}$ long, 2 $\mathrm{mm}$ wide. Lateral sepals oblong, obtuse apically, subfalcate, $4 \mathrm{~mm}$ long, $1 \mathrm{~mm}$ wide. Petals translucent white with a central longitudinal reddish-brown line; oblanceolate, obtuse apically, coherent to the dorsal sepal, glabrous, $4 \mathrm{~mm}$ long, $0.8 \mathrm{~mm}$ wide. Labellum crystalline white with green lateral lobes; pandurate, auriculate at the base, ecallose, $5.7 \mathrm{~mm}$ long (including the basal auricles), $3.3 \mathrm{~mm}$ wide; hypochile 2.6 $\mathrm{mm}$ long, $3.2 \mathrm{~mm}$ wide, margins entire, lateral lobes enfolding the column; basal auricles subfalcate, 1.5 $\mathrm{mm}$ long, $0.5 \mathrm{~mm}$ wide, inserted in the spur. Epichile transversely bilobed, sides slightly incurved to flat, 1.8 $\mathrm{mm}$ long, $3.3 \mathrm{~mm}$ wide, margin crenulate; apex retuse with a sinus $0.3 \mathrm{~mm}$ deep and $0.4 \mathrm{~mm}$ wide. Column reddish-cream, $4 \mathrm{~mm}$ long, $1.3 \mathrm{~mm}$ wide, stigma bilobed; anther brown, $1.2 \mathrm{~mm}$ long, $1 \mathrm{~mm}$ wide. Pollinia cuneate-obovate, white, each one $1.7 \mathrm{~mm}$ long, $0.5 \mathrm{~mm}$ wide; viscidium dark grey, rhombic, 3 $\mathrm{mm}$ wide. Fruit a fusiform capsule, $1.2 \mathrm{~cm}$ long, 0.5 $\mathrm{cm}$ thick. Most flowers developing into fruits.
Costa Rican ReCORDS: Heredia: Puerto Viejo de Sarapiquí, Estación Biológica La Selva, Sendero Tres Ríos $1550,10^{\circ} 26^{\prime} \mathrm{N}, 83^{\circ} 59^{\prime} \mathrm{W}$, alt. $50 \mathrm{~m}, 7$ Apr. 2000 (buds, flowers, fruits, leafless), Blanco, Horvitz, King, Johnson, \& Lange 1488 (USJ, CR, F, MO, SEL, M). Same locality, 18 Jun. 2000 (sterile, leafing), Blanco 1521 (USJ, CR, F, MO, SEL).

Cyclopogon obliquus has an interesting historical record. Even though the genus is otherwise exclusively Neotropical, it was first found growing spontaneously in the Bogor Botanic Gardens in western Java, and described in 1910 by Johannes Jacobus Smith - then director of the Herbarium Bogoriense - as a species of Spiranthes Rich. It was not until 1976 when it was collected again, this time in Hong Kong, and described as Manniella hongkongensis by $\mathrm{Hu}$ and Barretto. It was collected a few years later in El Salvador, and described by Garay as Pelexia hameri. A couple of years later, Garay himself recognized his species as synonymous with Smith's Spiranthes obliqua, transferring the latter to Pelexia. In 1994, Szlachetko transferred it once more, this time to the genus Cyclopogon. The latter convention is followed here.

Most recent treatments place this taxon under the genus Pelexia (Hamer 1984, 1990, 2001; MoraRetana \& García 1992, Dressler 1993, Ackerman 2000, Cribb \& Ormerod 2000). However, the combination of a short column, an oblong, fleshy, blunt rostellum, and a nectary that is totally adnate to the ovary, suggests a better placement in Cyclopogon (G. Salazar, pers. commun. 2001). On the other hand, Ackerman (2000) also used floral morphology to support a placement in Pelexia. Recent cladistic analyses based on DNA data (G. Salazar, unpubl.) indicate that these two genera are not as closely related to each other as previously assumed (e.g., Burns-Balogh \& Robinson 1983); therefore, molecular data will likely settle this species' systematic affinities.

Cyclopogon obliquus has also turned up in eastern Java (Comber 1990), Sri Lanka (Hamer 1984), Samoa (Cribb \& Ormerod 2000), Nicaragua (Hamer 1984, 2001), Guadeloupe, and Cuba (Ackerman 2000). Ackerman (2000) lists vouchers from most of these locations. According to Comber (1990), it also occurs in Argentina and Brazil, but no vouchers are cited. Though the species' geographical origin is unknown, it is clear it must be Neotropical, as are the rest of the species in both Cyclopogon and Pelexia.

This case is strikingly similar to that of Oeceoclades maculata (Lindl.) Lindl., an orchid that 

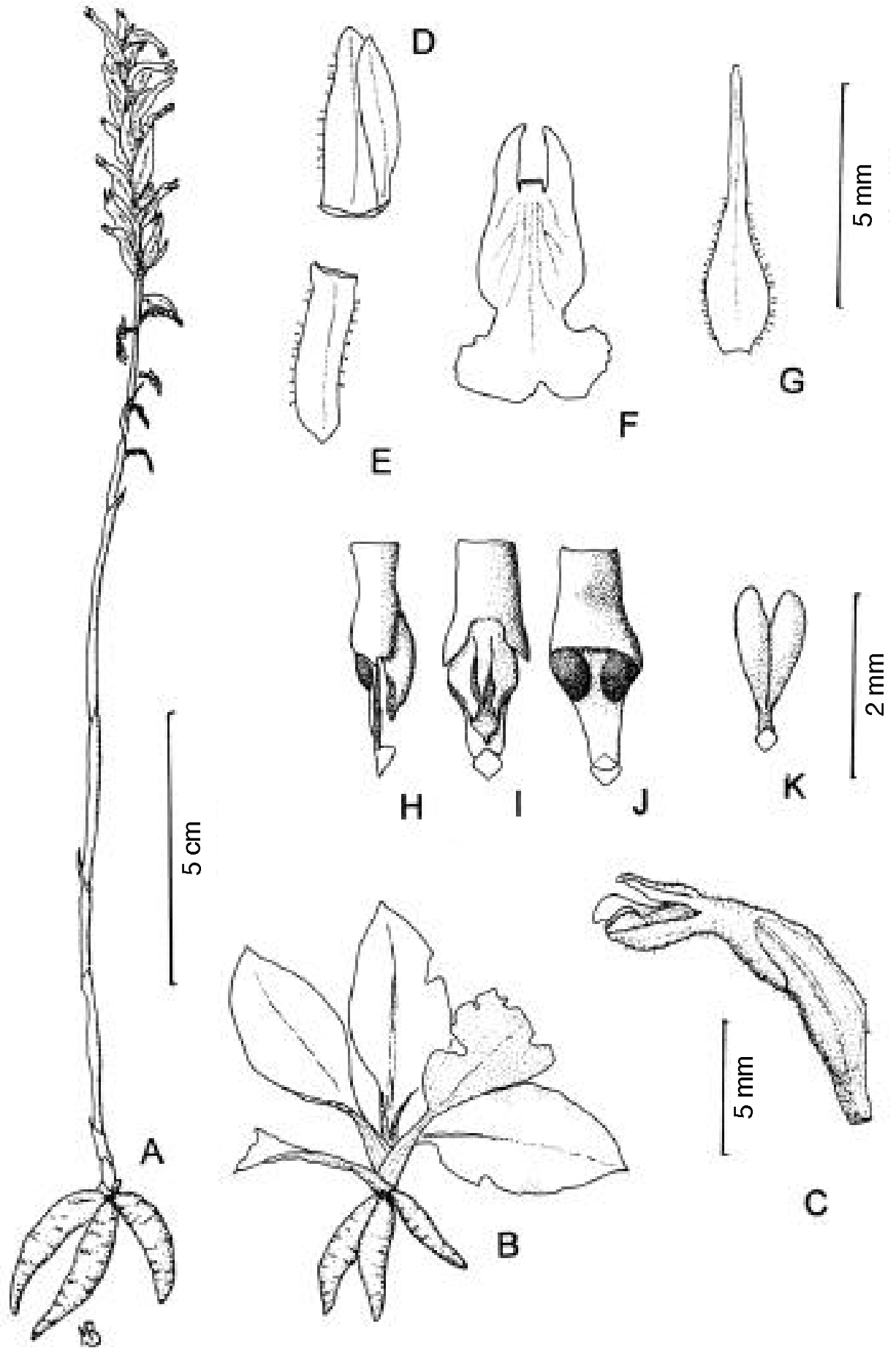

$\frac{E}{0}$
$\Omega$

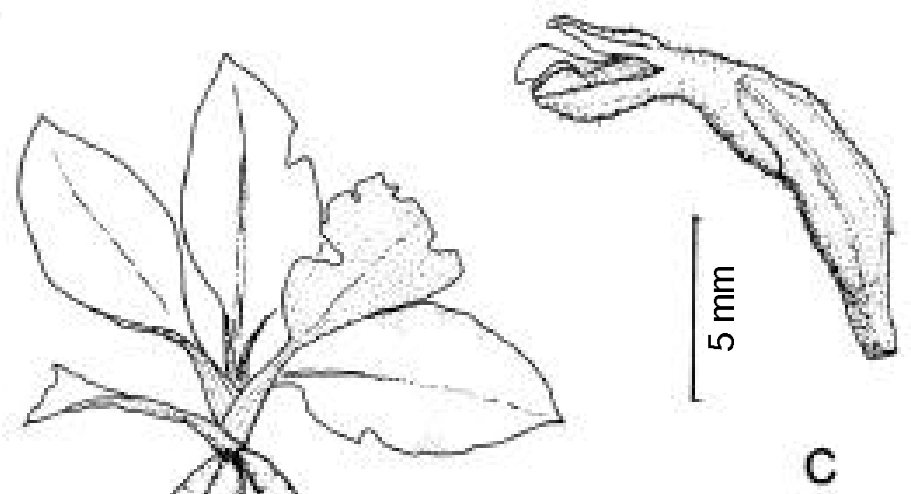

Figure 1. Cyclopogon obliquus (J.J. Sm.) Szlach. A - Flowering plant. B - Leafing plant (drawn from dried material; mature leaves lye flat on the ground in living plants). C - Flower, lateral view. D - Dorsal sepal and one coherent petal (the other removed). E - Lateral sepal. F - Lip. G - Floral bract. H - Column, lateral view. I - Column, dorsal view. J Column, ventral view. K - Pollinia. Illustration Vouchers: A, C-K, Blanco et al. 1488; B, Blanco 1521 (both, USJ). Drawings by the author. 
was described in 1821 from material collected wild in Brazil, and not found in its original African habitat until a few decades later (Stern 1988). The range of $O$. maculata has expanded very quickly in the Americas since its presumed introduction less than two centuries ago, and is presently found in most of tropical and subtropical America. It also has a long list of synonyms, mostly due to successive generic transfers (Stewart 1988). As in Cyclopogon obliquus (see "Pollination and Fruit Set" below), the success of O. maculata as an invasive species can be attributed in part to its self-pollinating capacity (González-Díaz \& Ackerman 1988).

Haвiтат: The only collection of Cyclopogon obliquus from what appears to be a natural habitat is McGillivary 85 (SEL, not found) (Hamer 1984, Cribb \& Ormerod 2000), in shady, wet, lower montane tropical forest in the Island of Ometepe in Nicaragua. The Costa Rican collection comes from a lowland site, even less seasonal as does the original type collection from Bogor. Comber (1990) notes that it has become more common in Tretes, as "the seasonal climate in East Java is obviously more to its liking than the almost everwet climate of Bogor". These observations, together with its deciduous behavior, support the idea that this species is better adapted to seasonally dry habitats.

Most of the collections from both the Americas and southeast Asia come from man-made habitats, especially lawns and pots (Garay 1978, Comber 1990, Cribb \& Ormerod 2000), suggesting that the seeds -or even whole plants- are accidentally transported in the soil of transplanted crops or ornamentals. This is the most likely scenario on how it got to Bogor in the first place; the Botanic Gardens had been actively importing plants from throughout the tropical world since the 1840's (Indonesian Institute of Sciences 2002). Cyclopogon obliquus is possibly more widely distributed in tropical and subtropical areas around the world than currently recognized, but flowering plants are easily overlooked due to their inconspicuous flowers and deciduous habit.

This might also explain why this species stayed undetected at La Selva, where an intensive floristic inventory program has taken place since 1979 (Hammel \& Grayum 1982, Hartshorn \& Hammel 1994). The inflorescences look like dry grass stems from a distance, and they merge with the colors of the surrounding leaf litter. I noticed them almost acciden- tally, but a careful inspection of the surrounding area revealed a small colony of 12 flowering individuals.

Plants were growing in alluvial soil right next to a paved trail which runs through a late secondary tropical wet forest, part of an abandoned -and recently removed-cacao plantation. The area next to the trail is periodically mowed, which probably facilitated the establishment of the plants by reducing competition for light. The leaves form a basal rosette and are held flat against the ground surface when fully expanded, so they avoid being damaged by the mowers. However, some trees with big leaves (e.g. Castilla elastica, Moraceae) grow in the same area, and their fallen leaves were observed to totally cover a few plants at the leafing stage. Light deprivation can be an important ecological constraint for photosynthesis, growth, and future reproductive output of individual plants, as shown by Willems et al. (2001) for a species of Spiranthes in the Netherlands.

There was a great variation in the size of flowering individuals. The smallest had an inflorescence $13 \mathrm{~cm}$ tall with nine flowers, and only three roots, the largest of which was $2.3 \mathrm{~cm}$ long. On the other hand, the tallest individual had an inflorescence of $32 \mathrm{~cm}$ with some 40 flowers and fruits, and with five roots present, up to $5 \mathrm{~cm}$ in length. There was a whole range of intermediate individuals (Fig. 1A shows one such "average" plant). This suggests that individual plants may start flowering when quite young. The larger plants also seemed to have been flowering for a longer period than the smaller ones, since some of the fruits lower in the spike had already dehisced; in the smaller individuals only flowers and developing fruits were present.

Phenology: The colony at La Selva was revisited periodically to gather phenological data. Two months after the original collection, in June 2000 (early rainy season, Sandford et al. 1994), numerous leafing plants were seen at the same spot, even when the flowering specimens had been previously removed as vouchers. By October, the plants still had their old leaves, but were not producing any new leaves. In late December (early dry season) the leaves had already disappeared, and no evidence of the presence of the plants remained at the surface. In mid May 2001 (end of the dry season of that year) most of the plants had already flowered and were fruiting, still leafless. Leaves were already present (and the inflorescences gone) by mid July, the last time I checked 
the colony.

Contrary to the pattern observed at La Selva, Comber (1990) reports that populations in Java flower at the beginning of the rainy season. In any case, all the available accounts of the species agree in that inflorescences and leaves never occur simultaneously. This deciduous habit is unusual in both Cyclopogon and Pelexia. Photographs of the flowering and leafing stages are presented by Comber (1990, as Spiranthes obliqua).

In South Florida, Calvo (1990) found that individual plants of Cyclopogon cranichoides (Griseb.) Schltr. can survive one or two years (and possibly more) in an underground condition, without producing any leaves. It is possible that $C$. obliquus has similar capabilities; if so, point counts on the number of individuals would likely underestimate the true population size. However, data from marked individual plants are lacking in this species.

Pollination and Fruit Set: Orchids in the "Pelexia-alliance" are adapted to bee pollination; the dorsal viscidium attaches to the underside of the labrum, and the fragile, friable pollinia assume a protected position when the proboscis is retracted (Singer \& Sazima 1999). Species of Cyclopogon appear to be specialized for pollination by halictid bees (Singer \& Cocucci 1999, Singer \& Sazima 1999). However, autogamy is reported for several species (Ackerman 1995, Singer \& Sazima 1999, van der Cingel 2001). The plants of C. obliquus at La Selva appear to be autogamous (at least facultatively), since virtually all the flowers develop into fruits (but see below). As in C. elatus (Sw.) Schltr. in Puerto Rico (Ackerman 1995), the simultaneous presence of buds, open flowers and dehisced fruits in some inflorescences indicate an ephemeral anthesis and rapid fruit ripening. Self-pollination becomes advantageous in conditions where suitable pollinators are absent, as might be the case in southeast Asia.

Both Catling (1982) and Singer \& Sazima (1999) report enlargement of ovaries without seed production in unpollinated flowers in several Spiranthine genera, including Cyclopogon. Although seeds were observed in some dehisced fruits in C. obliquus at $\mathrm{La}$ Selva, I cannot rule out the possibility that the plants require pollinator services in order to set seed, and the unpollinated flowers simply enlarge their ovaries without producing any seeds.

In May 2001, an inspection of the inflorescences revealed some indehisced fruits with no seeds within. Most of these had round exit holes, but a few had hymenopteran pupae inside (one per fruit), about 3 $\mathrm{mm}$ long. Unfortunately, no adults could be reared when inflorescences were put in clear plastic bags for a few days. Dissection of the pupae revealed they are Eurytomid wasps, possibly belonging to the large genus Eurytoma. Species of this genus have been found parasitizing fruits in several orchid species, including Pelexia adnata (Sw.) Spreng. in Belize (Catling \& Greenwood 1988). The absence of such seed predators in Indonesia might partly account for the apparent higher population densities of Cyclopogon obliquus there than in the Neotropics.

ACKNOWLEDGMENTS: I thank Carol Horvitz (University of Miami) for funding my stay at La Selva during fieldwork for a project assessing alluvial forest regeneration following removal of cacao trees, when flowering material was collected. Additional collecting was possible due to a research grant by the Andrew W. Mellon Foundation and the Organization for Tropical Studies. Gerardo Salazar (Jodrell Laboratory, Royal Botanic Gardens, Kew) provided much useful information and interesting discussions. Paul Hanson (Universidad de Costa Rica) identified the wasps. Carlos Ossenbach kindly provided several critical references. Robert Dressler, Carlos O. Morales, and Franco Pupulin made useful suggestions for the improvement of the manuscript.

\section{Literature Cited}

Ackerman, J. D. 1995. An orchid flora of Puerto Rico and the Virgin Islands. Mem. New York Bot. Gard. 73.

Ackerman, J. D. 2000. Notes on the Caribbean orchid flora. II. Lindleyana 15: 89-95.

Atwood, J. T. 1988. The vascular flora of La Selva Biological Station, Costa Rica: Orchidaceae. Selbyana 10: 76-145.

Burns-Balogh, P. \& Robinson, H. 1983. Evolution and phylogeny of the Pelexia Alliance (Orchidaceae: Spiranthoideae: Spiranthinae). Syst. Bot. 8: 263-268.

Calvo, R. 1990. Four-year growth and reproduction of Cyclopogon cranichoides (Orchidaceae) in South Florida. Amer. J. Bot. 77: 736-741.

Catling, P. M. 1982. Breeding systems of northeastern North American Spiranthes (Orchidaceae). Can. J. Bot. 60: 3017-3039.

Catling, P. M., \& Greenwood, E. W. 1988. Wasps and flies in orchid capsules. Orquídea (Méx.) 11: 277-279.

Comber, J. B. 1990. Orchids of Java. Kew, Royal Botanic Gardens.

Cribb, P. \& Ormerod, P. 2000. Notes on Orchidaceae from the Pacific Islands. Kew Bull. 55: 231-236. 
Dressler, R. L. 1993. Field Guide to the Orchids of Costa Rica and Panama. Ithaca, New York, Comstock/Cornell.

Garay, L. A. 1978. Studies in American Orchids. X. Bot. Mus. Leafl. Harv. Univ. 26(1): 1-38.

González-Díaz, N, \& Ackerman, J. D. 1988. Pollination, fruit set, and seed production in the orchid Oeceoclades maculata. Lindleyana 3: 150-155.

Hamer, F. 1981. Las Orquídeas de El Salvador. Suplemento III. Sarasota, The Marie Selby Botanical Gardens.

Hamer, F. 2001. Orchidaceae Juss. In: Stevens, W. D., Ulloa, C., Pool, A., \& Montiel, M. (eds.). Flora de Nicaragua. Tomo II. Monogr. Syst. Bot. Missouri Bot. Gard. 85: 1612-1860.

Hamer, F. 1984. Pelexia obliqua (J.J. Sm.) Garay. Icon. P1. Trop. 11: Orchids of Nicaragua, part 4. Plate 1072.

Hamer, F. 1990. Orchids of Central America: an illustrated field guide (M-Z). Selbyana 11 (Suppl.): 423-860.

Hammel, B. E. \& Grayum, M. 1982. Preliminary report on the flora project of La Selva Field Station, Costa Rica. Ann. Missouri Bot. Gard. 69: 420-425.

Hartshorn, G. S. \& Hammel, B.E. 1994. Vegetation Types and Floristic Patterns. In: McDade, L. A., Bawa, K. S., Hespenheide, H. A., \& Hartshorn, G. S. (eds.). La Selva: Ecology and Natural History of a Neotropical Rain Forest. p. 73-89. Chicago, The University of Chicago Press.

Hu, S. Y. 1977. The Genera of Orchidaceae in Hong Kong. The Chinese University Press.

Indonesian Institute of Sciences. 2002. History of Bogor Botanic Garden. Available online at URL: http://www.bogor.indo.net.id/kri/bhist.htm. Consulted on May 30, 2002.
Mora-Retana, D. E. \& García, J. B. 1992. Lista actualizada de las orquídeas de Costa Rica (Orchidaceae). Brenesia 37: 79-124.

Sandford, R. L., Paaby, P., Luvall, J. C., \& Phillips, E. 1994. Climate, Geomorphology, and Aquatic Systems. In: McDade, L. A., Bawa, K. S., Hespenheide, H. A., \& Hartshorn, G. S. (eds.). La Selva: Ecology and Natural History of a Neotropical Rain Forest. p. 19-33. Chicago, The University of Chicago Press.

Singer, R. B. \& Cocucci, A. A. 1999. Pollination mechanism in southern Brazilian orchids which are exclusively or mainly pollinated by halictid bees. Pl. Syst. Evol. 217: 101-117.

Singer, R. B. \& Sazima, M. 1999. The pollination mechanism in the 'Pelexia alliance' (Orchidaceae: Spiranthinae). Bot. J. Linn. Soc. 131: 249-262.

Stern, W. L. 1988. The long-distal dispersal of Oeceoclades maculata. Amer. Orch. Soc. Bull. 57: 960-971.

Stewart, J. 1988. A brief overview of the genus Oeceoclades. Amer. Orch. Soc. Bull. 57: 972-975.

Van der Cingel, N. A. 2001. An atlas of orchid pollination: America, Africa, Asia, and Australia. Rotterdam, A. A. Balkema.

Wilbur, R. L. 1994. Vascular plants: an interim checklist. In: McDade, L. A., Bawa, K. S., Hespenheide, H. A., \& Hartshorn, G. S. (eds.). La Selva: Ecology and Natural History of a Neotropical Rain Forest. p. 350-378. Chicago, The University of Chicago Press.

Willems, J. H., Balounova, Z., and Kindlmann, P. 2001. The effect of experimental shading on seed production and plant survival of Spiranthes spiralis (Orchidaceae). Lindleyana 16: 31-37. 